\title{
Genomic insights into Staphylococcus equorum KS1039 as a potential starter culture for the fermentation of high-salt foods
}

\author{
Jong-Hoon Lee ${ }^{1}$, Sojeong Heo ${ }^{1,2}$ and Do-Won Jeong ${ }^{2^{*}}$ (D)
}

\begin{abstract}
Background: Our previous comparative genomic analysis of Staphylococcus equorum KS1039 with five S. equorum strains illuminated the genomic basis of its safety and salt tolerance. However, a comprehensive picture of the cellular components and metabolic pathways involved in the degradation of macromolecules and development of sensory properties has not been obtained for S. equorum. Therefore, in this study, we examined the general metabolism of $S$. equorum based on information obtained from published complete genome sequences of six S. equorum strains isolated from different niches. Additionally, the utility of strain KS1039 as a starter culture for high-salt food fermentations was examined.
\end{abstract}

Results: All six S. equorum strains contained genes involved in glycolysis, the tricarboxylic acid cycle, and amino acid metabolic pathways, as well as color development. Moreover, the strains had the potential to produce acetoin, butanediol, and branched chain fatty acids, all of which are important flavor compounds. None of the strains contained decarboxylase genes, which are required for histamine and tyramine production. Strain KS1039 contained bacteriocin and CRISPR/Cas gene clusters, and experimental results suggested that these genes were functional in vitro.

Conclusions: The comparative genomic analysis carried out herein provides important information on the usefulness of S. equorum KS1039 as a starter culture for the fermentation of high-salt foods in terms of safety, salt tolerance, bacteriocin production, and foreign plasmid restriction.

Keywords: Staphylococcus equorum, Fermentation, Jeotgal, Starter, Bacteriocin, CRISPR/Cas system

\section{Background}

Jeotgal is the name used to collectively describe traditional Korean high-salt-fermented seafood products, which are made with seafood such as shrimps, oysters, and anchovies. It is often eaten as a side dish, used as a seasoning for kimchi and various soups, or as a dipping sauce with pork dishes. Jeotgal is made by adding up to $30 \%(\mathrm{w} / \mathrm{w})$ sea salt to various types of seafood, and becomes palatable through autolysis and microbial enzyme activities during subsequent fermentation, attaining rich

\footnotetext{
* Correspondence: jeongdw@dongduk.ac.kr; wony744@gmail.com Department of Food and Nutrition, Dongduk Women's University, Seoul 02748, Republic of Korea

Full list of author information is available at the end of the article
}

flavors and physical structures. Studies of the microbial structure and function in jeotgal have been performed to better understand the exact role of jeotgal-derived microorganisms [1-3]. However, the exact function of microorganisms in jeotgal production remains unclear, and starter cultures have not been implemented in the jeotgal industry.

To develop a more complete overview of the bacterial community in jeotgal, we evaluated the bacterial communities in two representative types of jeotgal using culture-based methods [3]. Coagulase-negative staphylococci (CNS) was identified as a major bacterial group, while Staphylococcus equorum was identified as the most dominant species. S. equorum has also frequently been 
detected in high-salt fermented meat products and cheeses in Europe [4-8]. It produces low molecular weight aroma compounds, such as esters, amino acids, aldehydes, and free fatty acids, through proteolysis and lipolysis in fermented foods. For this reason, S. equorum has been investigated as a component of starter cultures for fermentation of high-salt foods [9-13]. However, a small number of nosocomial infection cases caused by CNS species necessitates a safety assessment of potential industrial strains prior to their implementation in fermented food production [14].

S. equorum strain KS1039 was selected as a starter candidate from among many jeotgal-derived S. equorum strains after a series of safety assessments [9]. KS1039 was sensitive to 14 antibiotics, and was negative for hemolytic activity, biofilm formation, and biogenic amine production. Moreover, KS1039 exhibited efficient enzymatic activities, including protease and lipase activities, which are involved in the enhancement of sensory properties, and grew at a $\mathrm{NaCl}$ concentration of $25 \%(\mathrm{w} / \mathrm{v})$ [9]. In our recent comparative genomic analysis of KS1039 with five other S. equorum strains, we identified the genomic basis of its safety and salt tolerance [1]. However, a comprehensive picture of the cellular components and metabolic pathways involved in the degradation of macromolecules and the development of sensory properties has not been proposed for S. equorum. Therefore, in this study, we examined the general metabolism of $S$. equorum based on information obtained from the published complete genome sequences of six S. equorum strains isolated from different niches. Additionally, the superiority of KS1039 as a starter culture for high-salt food fermentation was illuminated through comparative genomic analysis.

\section{Methods}

\section{Bacterial strains and culture conditions}

S. equorum strain KS1039, originally isolated from jeotgal, was used in this study. The genome of KS1039 was fully sequenced in our previous study [15], and these sequencing results were used in the current study to deduce the metabolic pathways present in S. equorum. To experimentally validate the sequencing results, four additional S. equorum strains, KM1031 from Myeolchi-jeotgal, C2014 from Saeu-jeotgal, Mu2 from French smearripened cheese [16], and UMC-CNS-924 from bovine mastitis [17], were used. S. equorum strains were cultured in tryptic soy broth/agar (TSB/TSA) at $30{ }^{\circ} \mathrm{C}$ for $24 \mathrm{~h}$.

\section{Comparative genomics}

For comparative genomic analysis of the genome of KS1039 (GenBank accession number CP013114.1), the complete genome sequences of $S$. equorum KM1031 (NZ_CP013980.1), S. equorum C2014 (NZ_CP013714.1),
S. equorum subsp. equorum Mu2 (CAJL00000000.1), S. equorum UMC-CNS-924 (AVBD00000000.1), and S. equorum G8HB1 (LAKE00000000.1) were obtained from the NCBI Microbial Genomes database. The average nucleotide identities of the conserved genes among the genomes were identified using the Basic Local Alignment Search Tool (BLAST), and the data was used for comparative analysis [18]. Genome sequences of the S. equorum species involved in this study were uploaded to the Rapid Annotations using Subsystems Technology (RAST) server for SEED-based automated annotation, wholegenome sequence-based comparative analysis, and Kyoto Encyclopedia of Genes and Genomes (KEGG) metabolic pathway analysis [19]. Efficient Database framework for comparative Genome Analyses using BLAST score Ratios (EDGAR) was used for core genome, pan genome, and singleton analysis using S. equorum KS1039 as the reference genome [15]. Further comparative analyses were performed for specific regions and genes-of-interest using the BLASTN, BLASTX, and BLASTP tools.

\section{Physiological characterization}

Strains were characterized biochemically using the commercially available ID $32 \mathrm{STAPH}$ system according to the manufacturer's instructions (bioMérieux).

\section{Determination of bacteriocin activity}

The inhibitory activity of KS1039, along with that of the other S. equorum strains, was determined using the disk diffusion method on TSA agar at $30{ }^{\circ} \mathrm{C}$ for $24 \mathrm{~h}$, using Staphylococcus aureus RN4220 as an indicator. An overnight culture of $S$. aureus RN4220 grown in TSB was used to inoculate fresh TSB medium to a final concentration of $1 \%(\mathrm{v} / \mathrm{v})$, and then incubated at $30{ }^{\circ} \mathrm{C}$ to an optical density at $600 \mathrm{~nm}\left(\mathrm{OD}_{600}\right)$ of 1.0. The culture $(200 \mu \mathrm{L})$ was then poured onto TSA plates. Sterile paper disks were placed on the surface of each plate. $S$. equorum strains were cultured to stationary phase and then diluted in TSB to an $\mathrm{OD}_{600}$ of 1.0. This dilution was centrifuged at $5000 \times g$ for $30 \mathrm{~min}$ at $4{ }^{\circ} \mathrm{C}$, and the resulting supernatant was filtered using a $0.22-\mu \mathrm{m}$ filter. A $15-\mu \mathrm{L}$ aliquot of each of the supernatants was dropped onto separate disks on the TSA plates, and the antibacterial activity of each strain against $S$. aureus RN4220 was determined by halo formation.

\section{Plasmid electroporation}

$S$. equorum was transformed by electroporation as described by Löfblom et al. [20]. Briefly, overnight cultures of $S$. equorum KS1039, as well as the other four strains, were inoculated into fresh TSB medium and incubated to an $\mathrm{OD}_{600}$ of 0.5 . The cultures were chilled in an ice slurry for $10 \mathrm{~min}$, with all subsequent steps performed at $4{ }^{\circ} \mathrm{C}$ on ice, and then harvested at $4000 \times g$ for $10 \mathrm{~min}$. 
The pellets were resuspended in $1 / 10$ volume of $0.5 \mathrm{M}$ sucrose. The cells were then repeatedly centrifuged and resuspended, first in $1 / 10$, then in $1 / 50$, and finally in $1 / 100$ the volume of ice-cold $0.5 \mathrm{M}$ sucrose. Competent cells for electroporation $(100 \mu \mathrm{L})$ were frozen at $-70^{\circ} \mathrm{C}$.

Two plasmids, pYJ335, containing an erythromycin resistance gene [21], and pCL55, containing a chloramphenicol resistance gene [22], were used to check the electroporation efficiency of KS1039 and the other four strains. The two plasmids were selected on growth media containing $10 \mu \mathrm{g} / \mathrm{mL}$ of erythromycin and $5 \mu \mathrm{g} / \mathrm{mL}$ of chloramphenicol, respectively. For electroporation, electrocompetent cells were thawed on ice for $5 \mathrm{~min}$ prior to the addition of $10 \mathrm{ng}$ of plasmid DNA. The cells were incubated for $1 \mathrm{~min}$ on ice and then transferred to a chilled 2-mm electroporation cuvette (Bio-Rad) and pulsed at $25 \mathrm{kV} / \mathrm{cm}, 100 \Omega$, and $25 \mu \mathrm{F}$. A $900-\mu \mathrm{L}$ volume of TSB was immediately added to the cells, which were then incubated at $30{ }^{\circ} \mathrm{C}$ for $2 \mathrm{~h}$, before plating on TSA supplemented with the appropriate antibiotics. The plates were incubated at $37{ }^{\circ} \mathrm{C}$ for $24 \mathrm{~h}$. Electroporation results were confirmed by three independently performed assays.

\section{Results and discussion}

Central carbohydrate metabolism of $S$. equorum

Glycolysis and tricarboxylic acid (TCA) cycle

S. equorum KS1039 has the genetic potential to uptake glucose via either a phosphoenolpyruvate (PEP)-dependent phosphotransferase system (PTS) or a permease (Fig. 1, Additional file 1: Table S1). All genes encoding the enzymes involved in the glycolytic pathway (to pyruvate) were identified in the genome of S. equorum KS1039, as well as in the five other S. equorum strains (Fig. 1, Additional file 2: Table S2). All enzymes involved in the TCA cycle were also present in the six $S$. equorum strains (Additional file 2: Table S2).

\section{Carbohydrate utilization}

Different carbohydrate transport mechanisms were identified, including PEP-dependent sugar PTSs and permeases (Fig. 1). Genes for the utilization of cellobiose, maltose, mannose, mannitol, sucrose, and trehalose were also present, and these molecules could be taken up via a PTS; however, genes involved in raffinose, turanose, and sorbitol utilization were absent in S. equorum

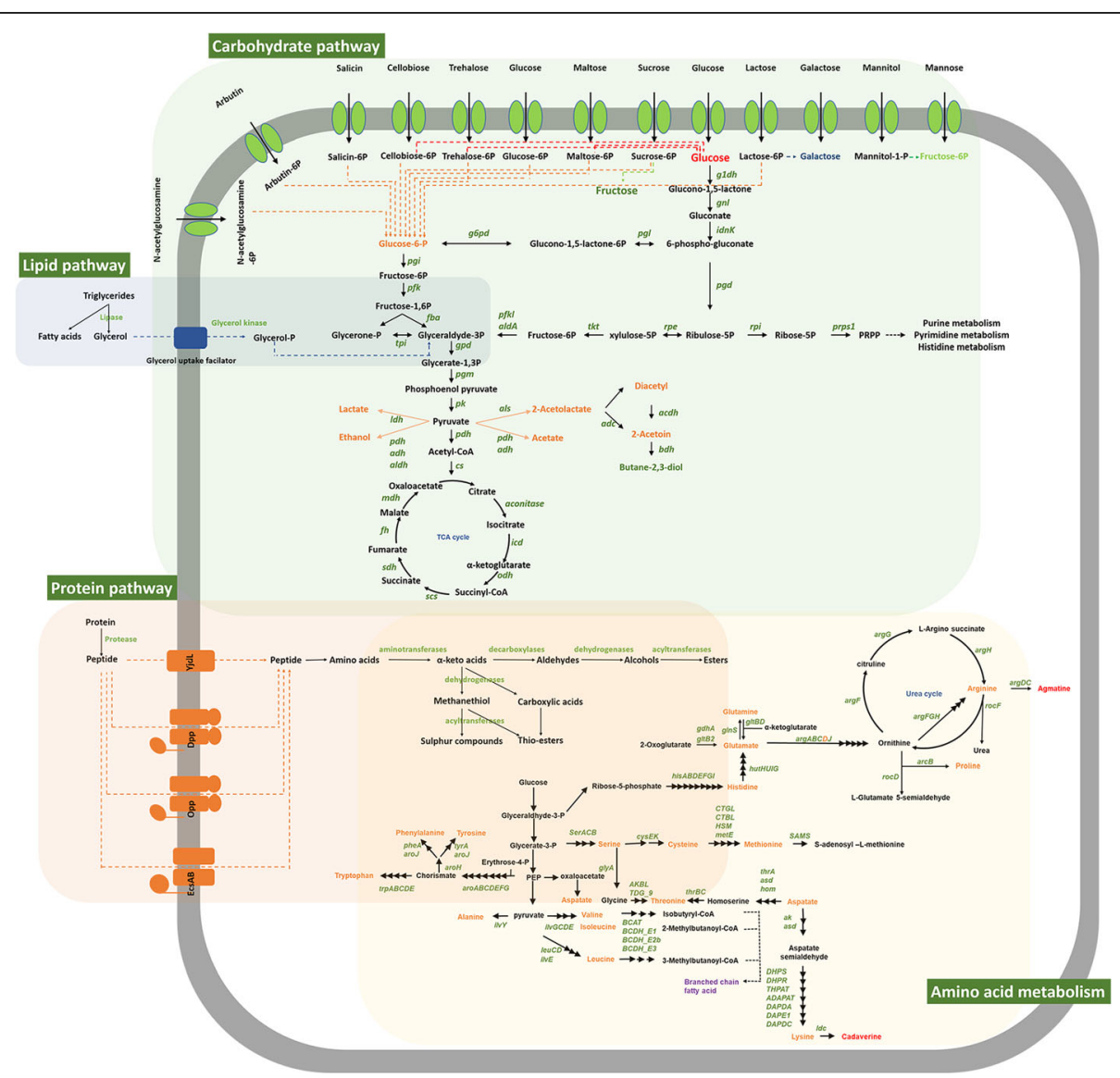

Fig. 1 Predicted membrane transport systems and metabolic pathways for carbohydrates, proteins, and lipids in Staphylococcus equorum. The names of the enzyme-encoding genes are depicted in green. Metabolites involved in fermentation pathways are depicted in orange. Black arrows correspond to potential active enzymatic reactions catalyzed by the corresponding gene products encoded by the S. equorum genome 
(Fig. 1 and Additional file 1: Table S1). Interestingly, the presence of a melibiose transporter gene was strainspecific. S. equorum had a fructose-specific PTS, but did not contain a permease gene, while a xylosespecific permease was detected along with a ribosespecific transporter (Additional file 1: Table S1).

S. equorum should be able to transport lactose via a lactose-specific PTS system. While S. aureus, Staphylococcus epidermidis, and Staphylococcus hominis can only utilize lactose via the tagatose-6-phosphate pathway [23], this pathway appeared to be missing in $S$. equorum. Instead, lactose-specific PTS and galactosespecific permease systems were detected in the genomes of $S$. equorum, along with two $\beta$-galactosidase genes (S. equorum KS1039 genome locus numbers SE1039_RS05770 and SE1039_RS12745).

To further investigate the carbohydrate utilization of the S. equorum strains, and to validate the genomic analysis results, we evaluated the biochemical characteristics of the five strains using an ID 32 STAPH system (Table 1). All five tested S. equorum strains utilized glucose, fructose,

Table 1 Phenotypic characteristics of Staphylococcus equorum isolates

\begin{tabular}{|c|c|c|c|c|c|}
\hline Biochemical assay & KS1039 & C2014 & KM1031 & Mu2 & UMC-CNS-924 \\
\hline \multicolumn{6}{|l|}{ Fermentation } \\
\hline D-glucose & + & + & + & + & + \\
\hline D-fructose & + & + & + & + & + \\
\hline D-mannose & + & + & + & + & + \\
\hline D-maltose & + & + & + & + & + \\
\hline D-lactose & + & + & + & + & + \\
\hline D-trehalose & + & + & + & + & + \\
\hline D-mannitol & + & + & + & + & + \\
\hline D-raffinose & - & - & + & - & + \\
\hline D-ribose & + & + & + & - & + \\
\hline D-cellobiose & + & + & + & + & + \\
\hline D-saccharose & + & + & + & + & + \\
\hline D-turanose & - & - & - & - & - \\
\hline L-arabinose & + & + & + & + & + \\
\hline $\mathrm{N}$-acetyl glucosamine & + & + & + & + & + \\
\hline Reduction of nitrate & + & + & + & + & + \\
\hline $\begin{array}{l}\text { Production of } \\
\text { acetoin }\end{array}$ & + & - & - & + & + \\
\hline Urease & + & + & + & + & + \\
\hline $\begin{array}{l}\text { Ornithine } \\
\text { decarboxylase }\end{array}$ & - & - & - & - & - \\
\hline B-Galactosidase & + & + & + & + & + \\
\hline Arginine arylamidase & - & - & - & - & - \\
\hline Alkaline phosphatase & - & - & - & - & - \\
\hline $\begin{array}{l}\text { Pyrrolidonyl } \\
\text { arylamidase }\end{array}$ & - & - & - & - & - \\
\hline
\end{tabular}

mannose, maltose, lactose, trehalose, mannitol, cellobiose, saccharose, and arabinose, which agreed with the results of the genetic analysis. Our results showed that three strains, KS1039, C2014, and Mu2, could not utilize raffinose, while the remaining two strains, KM1031 and UMC-CNS-924, could. KS1039 and Mu2 did not appear to contain the gene cluster required for melibiose/raffinose utilization (Additional file 3: Figure S1), or an $\alpha$ galactosidase gene. Although $\mathrm{C} 2014$ did contain the $\alpha$ galactosidase gene, a melibiose transporter was not identified in its genome sequence. S. equorum has been reported as a species that does not ferment raffinose [13]. However, we previously identifed a strain that could utilize raffinose [24], which is supported by the genetic information determined in this study.

\section{Pentose phosphate pathway}

Most genes involved in the pentose phosphate pathway were present in all six S. equorum strains (Additional file 4: Table S3). The strains contained gluconolactonaseencoding genes, and thus should be able to form 6phosphgluconoate via glucono-1,5-lactone for glycolysis (Fig. 1). A ribose transport system was present in all six strains, while an $\mathrm{ABC}$ transporter gene was missing in Mu2 (Additional file 1: Table S1, Additional file 5: Figure S2), resulting in a lack of ribose utilization by Mu2 (Table 1). In the presence of ribose, S. equorum could produce important compounds via the pentose phosphate pathway by uptake of ribose. However, further studies are required to determine whether the lack of ribose transport is restricted to Mu2.

\section{Protein and amino acid metabolism of $S$. equorum Amino acid biosynthesis}

In silico prediction of the amino acid biosynthesis pathways in S. equorum was performed (Fig. 1, Additional file 6: Table S4). The genomes of the six strains appeared to contain loci coding for all of the enzymes required for the biosynthesis of all amino acids, with the exception of asparagine. Asparagine is synthesized from L-aspartate by asparagine synthase or via the aspartate-ammonia ligase reaction. However, the six S. equorum strains did not contain genes encoding any of the required enzymes, suggesting that S. equorum might be prototrophic for all amino acids except asparagine.

\section{Proteolytic system}

The six S. equorum strains contained a proteolytic system composed of secreted proteases, amino acid and peptide transport systems required for import, and a set of intracellular peptidases involved in the hydrolysis of peptides (Fig. 1). Multiple copies of serine protease and CAAX amino terminal protease genes were detected (Additional file 7: Table S5). The serine protease was 
similar to the well-characterized secreted protease SspA from $S$. aureus, which is proteolytically cleaved to produce a mature and functional enzyme [25]. CAAX amino terminal proteases demonstrate protease activity when anchored to the membrane [26]. Therefore, we assumed that these proteases play a role in protein degradation.

\section{Amino acid and peptide transport systems}

There is limited experimental data on S. equorum amino acid and peptide transport systems. Although no amino acid or di-tripeptide transport systems have been characterized in detail in $S$. equorum, this species is frequently detected in protein-rich fermented foods [13, 16], and has been linked to aroma production from amino acids [11]. Therefore, characterization of any oligopeptide ABC transport systems in S. equorum would be useful to help explain the role of this species in fermented foods.

The genomes of the six $S$. equorum strains contained a proton-dependent di-tripeptide transporter system, YjdL. In addition, three $\mathrm{ABC}$ transport systems, Opp, EcsAB, and Dpp, were detected (Fig. 1, Additional file 8: Table S6). The Opp transporter is composed of an oligopeptide ABC transporter (OppA), two membrane proteins that form the permease (OppB and $\mathrm{OppC})$, and two ATP-binding proteins (OppD and OppF) that provide energy for the system. The oppABCDF genes were organized in an operon. The Ecs transporter is also composed of an ABC transporter $(E \operatorname{cs} A)$, permease proteins $(E c s B)$, and a protein of unknown function (EcsC) that has been suggested to be involved in peptide transport [27]. In the six strains, $e \operatorname{cs} A$ and $e \operatorname{cs} B$ were detected in the absence of ecs $C$. In addition, the Dpp transporter operon in these strains appeared to be incomplete, with only $d p p C$ and $d p p D$ being detected. Despite these findings, the main systems for peptide and amino acid transport were identified in the genomes of the S. equorum strains, although some of the genes appeared to have been subjected to breakage, rearrangement, and duplication processes. Consequently, we hypothesize that the Opp transport system is likely to play the greatest role in peptide transport into the cell.

\section{Characteristics of S. equorum involved in food fermentations \\ Color development}

$S$. equorum plays a role in color development of fermented meat by the reduction of nitrates to nitrite, and then to nitrous oxide [28]. Related gene clusters, nitrate reductase (nar), nitrous oxide reductase (nor), and nitrite reductase (nir), were detected in the S. equorum KS1039 genome, as well as in other strains (Additional file 9: Figure S3). The nitrate reductase activity of S. equorum KS1039 has previously been reported in laboratory media supplemented with nitrate [9].

\section{Flavor development}

Butane-2,3-diol are produced from low molecularweight volatile compounds such as diacetyl and acetoin by microorganisms. Lactic acid bacteria produce both diacetyl and acetoin, which are recognized as buttery aroma compounds. According to the genomic analysis performed in the current study, most S. equorum strains possess genes involved in the production of these compounds. They appear to be generated via $\mathrm{NAD}^{+}$regeneration from pyruvate using three genes: als ( $\alpha$-acetolactate synthase), $a d c$ ( $\alpha$-acetolactate decarboxylase), and $b d h$ (2,3-butanediol dehydrogenase) (Fig. 1, Additional file 2: Table S2). adc was not identified in C2014. Pyruvate may be converted into acetate, lactate, and ethanol, all of which contribute to the sensory properties. All of the S. equorum strains contained the genes responsible for the production of these three products.

In addition, the catabolism of amino acids plays an important role in providing precursors for the biosynthesis of amino acids, nucleotides, and vitamins, generating energy in nutrient-limited environments, increasing intracellular $\mathrm{pH}$, and production of ester and sulfur compounds. These compounds contribute to the aroma of fermented foods. Catabolism of amino acids is commonly initiated by a transamination step, requiring the presence of $\alpha$-ketoglutarate as the amino group acceptor, to produce $\alpha$-keto acids. All of the S. equorum genomes contained several aminotransferase genes, including two aspartate aminotransferases (SE1039_RS08735 and SE1039_RS08745), one aromatic aminotransferase (SE1039_RS02785), and one branched chain amino acid aminotransferase (SE1039_RS01825). Two glutamate dehydrogenase genes (SE1039_RS01790 and SE1039_RS03600) are required to produce $\alpha$-ketoglutarate from amino acid transamination (Fig. 1). Experimental data showed that S. equorum produced methyl-branched ketones, compounds involved in aroma, from leucine, isoleucine, and valine [11]. These results supported the data generated from the genetic analysis of S. equorum (Fig. 1).

\section{Absence of biogenic amine production}

Recently, several starter candidates have been selected to reduce the safety hazards involved with fermentation [29-34]. Biogenic amines produced by naturally occurring microorganisms are significant safety hazards in protein-rich fermented foods. The major biogenic amines found in foods are putrescine, cadaverine, histamine, tyramine, tryptamine, 2-phenyl-ethylamine, spermine, agmatine, and spermidine. The formation of biogenic amines in fermented foods has been attributed to the decarboxylase activity of bacteria involved in fermentation [35]. Among the biogenic amines, histamine and tyramine are hazardous to human health because of 
their vasoactive and psychoactive properties [36]. Although none of the enzymes involved in decarboxylation of histidine and tyramine were identified in the genomes of the six S. equorum strains, the lysine decarboxylase gene (SE1039_RS01180), which is involved in cadaverine production, was identified. However, our previous study showed that KS1039 does not produce cadaverine, histamine, putrescine, or tyramine [9]. Other coagulasenegative staphylococci isolated from doenjang, including S. saprophyticus, S. succinus, and S. xylosus, produced non-significant amounts of cadaverine and putrescine, but did not produce histamine and tyramine [36]. Therefore, the lack of genes related to histamine and tyramine production in the genome of $S$. equorum supports its potential implementation in food fermentation processes.

\section{Useful characteristics of KS1039 as a starter culture for food fermentations \\ Bacteriocin production}

Production of bacteriocins, such as epidermin, epicidin 280, hyicin 3682, and nukacin L217, has been reported in $S$. epidermidis $\mathrm{Tu}$ 3298, S. epidermidis BN280, Staphylococcus hycius 3682, and Staphylococcus chromogenes L217, respectively [37-40]. KS1039 contained the entire lactococcin 972 operon, including the prebacteriocin (SE1039_RS11380) and immunity protein (SE1039_RS11385) genes (Fig. 2). The lactococcin 972 operon, a bacteriocin gene cluster, was first identified in Lactococcus lactis, where the corresponding proteins had a bactericidal effect on sensitive lactococci [41]. The lactococcin 972 operon encodes a pre-bacteriocin protein that forms a homodimer that is lethal to target strains, as well as an immunity protein that protects the producing cell from the action of the bacteriocin. Unlike KS1039, the operon was not present in Mu2, while the four other strains, KM1031, C2014, G8HB1, and
UMC-CNS-924, possessed one or other of the two genes (Fig. 2). Expression of the lactococcin 972 operon in KS1039 was confirmed experimentally by examining the antibacterial activity of $S$. equorum strains against $S$. aureus (Additional file 10: Figure S4).

Consumers frequently demand additional health properties from fermented foods, such as prevention of food poisoning. Therefore, a bacterial strain with bacteriocin-producing abilities, such as KS1039, has a unique advantage as a starter culture for fermented food production, as it would function as a natural preservative and prevent the growth of bacterial pathogens.

\section{Clustered regularly interspaced short palindromic repeat (CRISPR)/Cas systems}

CRISPR/Cas systems have the ability to acquire short pieces of DNA (spacers) that provide immunity against subsequent exposure to phages and plasmids carrying matching sequences [42-44]. The detailed mechanism by which CRISPR/Cas systems provide resistance to foreign DNA is currently the subject of much investigation. Several CRISPR/Cas systems have been identified in Streptococcus thermophilus, and are assumed to aid in the survival of the bacterium in milk [45]. The CRISPR/ Cas systems of $S$. thermophilus decreased the uptake and dissemination of undesirable plasmid-encoded genetic elements in Escherichia coli [46]. CRISPR/Cas sequences were detected in the genome of KS1039 (SE1039_RS13110-SE1039_RS13150), but were not present in the other five published S. equorum genomes (C2014, KM1031, Mu2, UMC-CNS-924, and G8HB1). The KS1039 CRISPR/Cas region spans approximately $8.5 \mathrm{~kb}$, and consists of nine cas genes: cas 1, cas2, csm1, csm2, cmr4, csm4, csm5, csm6, and cas6 (Fig. 3). Generally, CRISPR consist of short conserved repeat sequences interspaced by unique DNA sequences of similar size,

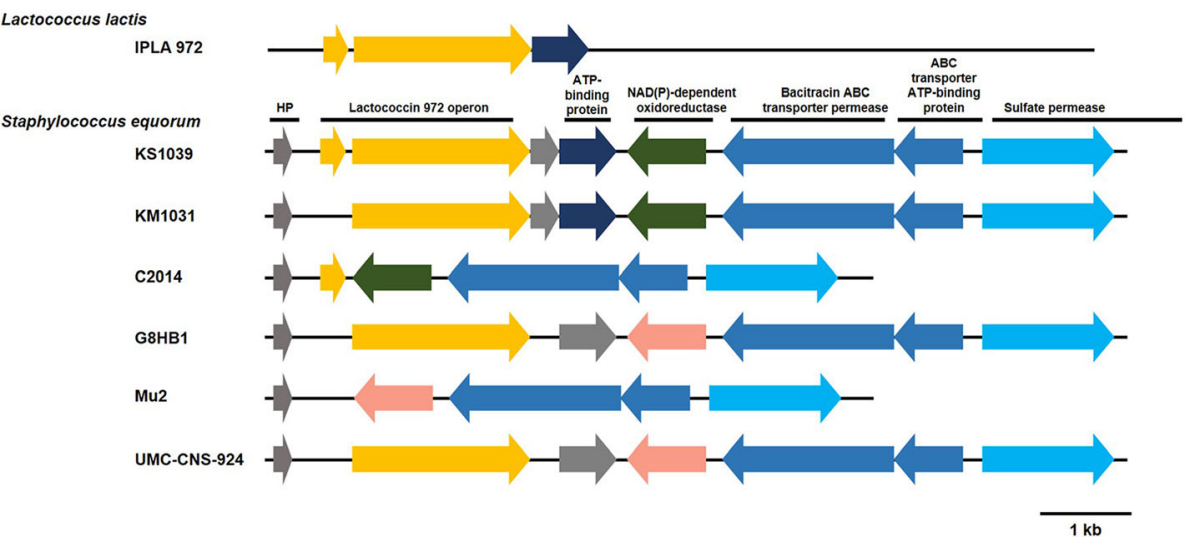

Fig. 2 Genetic organization of the lactococcin 972 cluster from Staphylococcus equorum isolates 


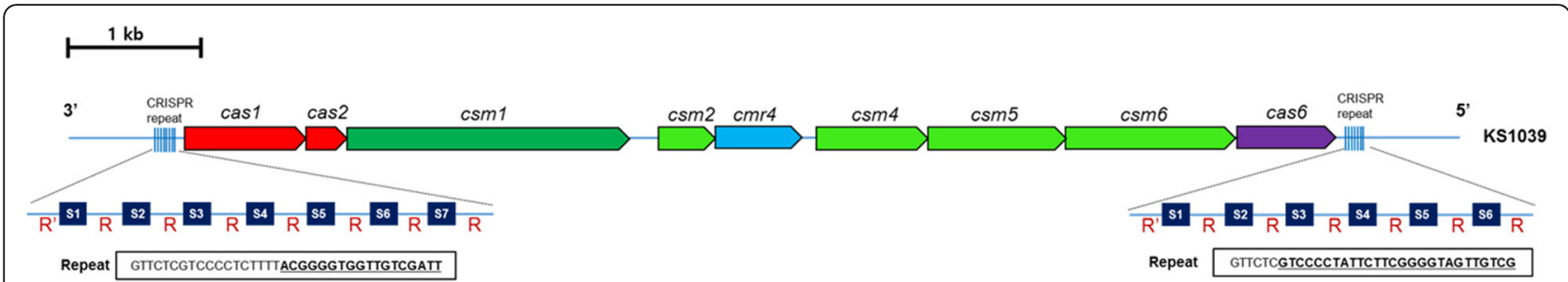

Fig. 3 CRISPR/Cas system of Staphylococcus equorum KS1039

called spacers. Two different repeat sequences with unique DNA sequences were detected in the flanking regions of cas genes in KS1039. It was reported that the unique DNA sequences originate from phage or plasmid DNA, and when foreign genes containing unique DNA sequences are inserted into bacteria, Cas proteins interfere with the invasive DNA through digestion during recombination between the invasive and host DNA [43, 44, 46, 47]. Therefore, we hypothesize that the CRISPR/Cas system could prevent the acquisition of foreign virulence genes by KS1039, which does not possess any known virulence genes [1].

To prove our hypothesis, we checked the transformation efficiency of KS1039 using plasmids pYJ335 and pCL55 (Table 2). Interestingly, no KS1039 transformants were obtained for either plasmid, whereas pYJ335 was transformed into the other $S$. equorum strains at frequencies of $5.9 \times 10^{-4}$ to $5.2 \times 10^{-8}$ colony-forming units $(\mathrm{cfu}) / \mathrm{ml}$. In particular, multidrug-resistant strain KM1031 showed high transformation efficiency. As plasmid pCL55 carries a chloramphenicol resistance marker, transformation experiments using this plasmid could not be carried out in strain KM1031, which shows resistance to chloramphenicol. However, pCL55 could be transformed into strains C2014, Mu2, and UMCCNS-924 at frequencies of $5.8 \times 10^{-8}, 2.4 \times 10^{-6}$, and $4.5 \times 10^{-8} \mathrm{cfu} / \mathrm{ml}$, respectively. These results supported the hypothesis that CRISPR/Cas sequences in KS1039 prevent plasmid acquisition, again suggesting

Table 2 In vitro transformation efficiency of pYJ335 and pCL55 into Staphylococcus equorum strains

\begin{tabular}{lll}
\hline Strain & \multicolumn{2}{l}{ Transformation rate (T/C; cfu/ml) } \\
\cline { 2 - 3 } & pYJ335 & pCL55 \\
\hline S. equorum KS1039 & - & - \\
S. equorum C2014 & $4.0 \times 10^{-7}$ & $5.8 \times 10^{-8}$ \\
S. equorum KM1031 & $5.9 \times 10^{-4}$ & - \\
S. equorum Mu2 & $1.4 \times 10^{-8}$ & $2.4 \times 10^{-6}$ \\
S. equorum UMC-CNS-924 & $5.2 \times 10^{-8}$ & $4.5 \times 10^{-8}$ \\
\hline
\end{tabular}

Cell counts represent the mean values of three independent replicates $\mathrm{T}$, transformed cell counts per $1 \mathrm{ml}$; C, competent cell count per $1 \mathrm{ml}$ Transformants were confirmed by plasmid identification that S. equorum KS1039 is a good starter candidate for fermented foods.

\section{Conclusions}

Analyses of the genome sequences of $S$. equorum KS1039 and five other S. equorum strains accurately identified the presence of metabolic pathways for carbohydrates and proteins. Thus, these analyses could shed light on how certain strains contribute to food fermentation, and may be useful in selecting optimal starter candidates based on appropriate sensory properties. As a starter candidate, S. equorum KS1039 possessed useful gene clusters, including those for bacteriocin production and a CRISPR/Cas system, which were not present in the other strains. Experimental results confirmed that S. equorum KS1039 exhibited bacteriocin activity, and that the CRISPR/Cas system prevented the uptake of foreign plasmid DNA. Therefore, S. equorum KS1039 displays the desirable properties of a starter culture for the fermentation of high-salt foods with regards to safety, salt tolerance, bacteriocin production, and foreign plasmid restriction.

\section{Additional files}

Additional file 1: Table S1. List of genes involved in sugar transport systems. (DOCX $25 \mathrm{~kb}$ )

Additional file 2: Table S2. List of genes involved in carbohydrate metabolism. (DOCX $22 \mathrm{~kb}$ )

Additional file 3: Figure S1. Genetic organization of the genes involved in melibiose/raffinose utilization in S. equorum. (DOCX 48 kb)

Additional file 4: Table S3. List of genes involved in the pentose phosphate pathway. (DOCX $20 \mathrm{~kb}$ )

Additional file 5: Figure S2. Genetic organization of the ribose operon in $S$. equorum. (DOCX $70 \mathrm{~kb}$ )

Additional file 6: Table S4. List of genes involved in amino acid biosynthesis. (DOCX $33 \mathrm{~kb}$ )

Additional file 7: Table S5. List of genes coding for proteases and peptidases. (DOCX $20 \mathrm{~kb}$ )

Additional file 8: Table S6. List of the genes involved in protein and peptide transport systems. (DOCX $19 \mathrm{~kb}$ )

Additional file 9: Figure S3. Genetic organization of nitrogen metabolism in S. equorum. (DOCX $51 \mathrm{~kb}$ )

Additional file 10: Figure S4. Growth inhibition of $S$. aureus by $S$. equorum strains. S. aureus RN4220 was used as an indicator strain. (DOCX $336 \mathrm{~kb})$ 


\section{Abbreviations}

BLAST: Basic Local Alignment Search Tool; CNS: Coagulase-negative staphylococci; CRISPR: Clustered regularly-interspaced short palindromic repeat; EDGAR: Efficient Database framework for comparative Genome Analyses using BLAST score Ratios; KEGG: Kyoto Encyclopedia of Genes and Genomes; PEP: Phosphoenolpyruvate; PTS: Phosphotransferase system; RAST: Rapid Annotations using Subsystems Technology; TCA: Tricarboxylic acid; TSA: Tryptic soy agar; TSB: Tryptic soy broth

\section{Acknowledgments}

S. equorum Mu2 was kindly provided by Dr. Francoise Irlinger of the Institut National de la Recherche Agronomique, Paris, France. S. equorum UMC-CNS924 was kindly provided by Dr. John R. Middleton of the University of Missouri, Columbia, MI, USA. We thank Tamsin Sheen, PhD, from Edanz Group (www.edanzediting.com/ac) for editing a draft of this manuscript.

\section{Funding}

This research was supported by the Basic Science Research Program through the National Research Foundation of Korea (NRF), funded by the Ministry of Education (NRF-2016R1D1A1B01011421 and NRF-2016R1D1A1B03930239). The funders had no role in study design, data collection and analysis, decision to publish, or preparation of the manuscript.

\section{Availability of data and materials}

The genomic sequence of strain KS1039 has been deposited in the GenBank database under accession number CP013114, and the strain has been deposited in the Korean Culture Center of Microorganisms under the accession number KCCM 43182

\section{Authors' contributions}

Conceived and designed the experiments: JHL and DWJ. Performed the experiments: SH. Analyzed the data: JHL, SH, and DWJ. Wrote the paper: JHL and DWJ. All authors read and approved the final manuscript.

\section{Ethics approval and consent to participate}

Not applicable. No human or animal material was directly used in this study.

\section{Consent for publication}

Not applicable.

\section{Competing interests}

The authors declare that they have no competing interests.

\section{Publisher's Note}

Springer Nature remains neutral with regard to jurisdictional claims in published maps and institutional affiliations.

\section{Author details}

'Department of Food Science and Biotechnology, Kyonggi University, Suwon 16227, Republic of Korea. ${ }^{2}$ Department of Food and Nutrition, Dongduk Women's University, Seoul 02748, Republic of Korea.

\section{Received: 4 May 2017 Accepted: 5 February 2018}

\section{Published online: 13 February 2018}

\section{References}

1. Jeong DW, Heo S, Ryu S, Blom J, Lee JH. Genomic insights into the virulence and salt tolerance of Staphylococcus equorum. Sci Rep. 2017;7:5383.

2. Jung J, Choi S, Jeon CO, Park W. Pyrosequencing-based analysis of the bacterial community in Korean traditional seafood, ojingeo jeotgal. J Microbiol Biotechnol. 2013;23:1428-33.

3. Guan L, Cho KH, Lee JH. Analysis of the cultivable bacterial community in jeotgal, a Korean salted and fermented seafood, and identification of its dominant bacteria. Food Microbiol. 2011;28:101-13.

4. Blaiotta G, Pennacchia C, Villani F, Ricciardi A, Tofalo R, Parente E. Diversity and dynamics of communities of coagulase-negative staphylococci in traditional fermented sausages. J Appl Microbiol. 2004;97:271-84.

5. Mauriello G, Casaburi A, Blaiotta G, Villani F. Isolation and technological properties of coagulase negative staphylococci from fermented sausages of southern Italy. Meat Sci. 2004;67:149-58.
6. Corbiere Morot-Bizot S, Leroy S, Talon R. Staphylococcal community of a small unit manufacturing traditional dry fermented sausages. Int J Food Microbiol. 2006;108:210-7.

7. Bockelmann W, Willems KP, Neve H, Heller KH. Cultures for the ripening of smear cheeses. Int Dairy J. 2005;15:719-32.

8. Kastman EK, Kamelamela N, Norville JW, Cosetta CM, Dutton RJ, Wolfe BE. Biotic interactions shape the ecological distributions of Staphylococcus species. MBio. 2016;7:e01157-16.

9. Jeong DW, Han S, Lee JH. Safety and technological characterization of Staphylococcus equorum isolates from jeotgal, a Korean high-salt-fermented seafood, for starter development. Int J Food Microbiol. 2014;188:108-15.

10. Deetae $P$, Bonnarme P, Spinnler HE, Helinck S. Production of volatile aroma compounds by bacterial strains isolated from different surface-ripened French cheeses. Appl Microbiol Biotechnol. 2007;76:1161-71.

11. Sondergaard AK, Stahnke LH. Growth and aroma production by Staphylococcus xylosus, S. carnosus and S. equorum - a comparative study in model systems. Int J Food Microbiol. 2002;75:99-109.

12. Fulladosa E, Garriga M, Martin B, Guardia MD, Garcia-Regueiro JA, Arnau J. Volatile profile and microbiological characterization of hollow defect in drycured ham. Meat Sci. 2010;86:801-7.

13. Place RB, Hiestand D, Gallmann HR, Teuber M. Staphylococcus equorum subsp. linens, subsp. nov., a starter culture component for surface ripened semi-hard cheeses. Syst Appl Microbiol. 2003;26:30-7.

14. Irlinger F. Safety assessment of dairy microorganisms: coagulase-negative staphylococci. Int J Food Microbiol. 2008;126:302-10.

15. Jeong DW, Na H, Ryu S, Lee JH. Complete genome sequence of Staphylococcus equorum KS1039 isolated from Saeu-jeotgal, Korean highsalt-fermented seafood. J Biotechnol. 2016;219:88-9.

16. Irlinger F, Loux V, Bento P, Gibrat JF, Straub C, Bonnarme P, Landaud S, Monnet C. Genome sequence of Staphylococcus equorum subsp. equorum Mu2, isolated from a French smear-ripened cheese. J Bacteriol. 2012;194:5141-2.

17. Calcutt MJ, Foecking MF, Hsieh HY, Perry J, Stewart GC, Middleton JR Genome sequence analysis of Staphylococcus equorum bovine mastitis isolate UMC-CNS-924. Genome Announc. 2013;1:e00840-13.

18. Goris J, Konstantinidis KT, Klappenbach JA, Coenye T, Vandamme P, Tiedje JM. DNA-DNA hybridization values and their relationship to whole-genome sequence similarities. Int J Sys Evol Microbiol. 2007;57:81-91.

19. Aziz RK, Bartels D, Best AA, DeJongh M, Disz T, Edwards RA, Formsma K, Gerdes S, Glass EM, Kubal M, et al. The RAST server: rapid annotations using subsystems technology. BMC Genomics. 2008;9:75.

20. Lofblom J, Kronqvist N, Uhlen M, Stahl S, Wernerus H. Optimization of electroporation-mediated transformation: Staphylococcus carnosus as model organism. J Appl Microbiol. 2007;102:736-47.

21. Ji Y, Marra A, Rosenberg M, Woodnutt G. Regulated antisense RNA eliminates alpha-toxin virulence in Staphylococcus aureus infection. J Bacteriol. 1999;181: 6585-90.

22. Lee $\mathrm{CY}$, Buranen $\mathrm{SL}$, Ye ZH. Construction of single-copy integration vectors for Staphylococcus aureus. Gene. 1991;103:101-5.

23. Götz F, Bannerman T, Schleifer K-H. The genera Staphylococcus and Macrococcus. PRO. 2006; $4: 5-75$

24. Jeong DW, Kim HR, Han S, Jeon CO, Lee JH. A proposal to unify two subspecies of Staphylococcus equorum: Staphylococcus equorum subsp. equorum and Staphylococcus equorum subsp. linens. Antonie Van Leeuwenhoek. 2013;104:1049-62.

25. Rice K, Peralta R, Bast D, de Azavedo J, McGavin MJ. Description of Staphylococcus serine protease (ssp) operon in Staphylococcus aureus and nonpolar inactivation of sspA-encoded serine protease. Infect Immun. 2001; 69:159-69.

26. Boyartchuk VL, Ashby MN, Rine J. Modulation of Ras and a-factor function by carboxyl-terminal proteolysis. Sci. 1997;275:1796-800.

27. Heinrich J, Lunden T, Kontinen VP, Wiegert T. The Bacillus subtilis ABC transporter EcsAB influences intramembrane proteolysis through RasP Microbiol. 2008;154:1989-97.

28. Hammes WP, Hertel C. New developments in meat starter cultures. Meat Sci. 1998;49S1:S125-38.

29. Perin LM, Miranda RO, Todorov SD, Franco BD, Nero LA. Virulence, antibiotic resistance and biogenic amines of bacteriocinogenic lactococci and enterococci isolated from goat milk. Int J Food Microbiol. 2014;185:121-6.

30. Udomsil N, Rodtong S, Choi YJ, Hua Y, Yongsawatdigul J. Use of Tetragenococcus halophilus as a starter culture for flavor improvement in fish sauce fermentation. J Agri Food Chem. 2011;59:8401-8. 
31. Ammor MS, Mayo B. Selection criteria for lactic acid bacteria to be used as functional starter cultures in dry sausage production: an update. Meat Sci. 2007;76:138-46

32. Leroy F, Verluyten J, De Vuyst L. Functional meat starter cultures for improved sausage fermentation. Int J Food Microbiol. 2006;106:270-85.

33. Shukla S, Lee JS, Park HK, Yoo JA, Hong SY, Kim JK, Kim M. Effect of novel starter culture on reduction of biogenic amines, quality improvement, and sensory properties of doenjang, a traditional Korean soybean fermented sauce variety. J Food Sci. 2015;80:M1794-803.

34. Suzzi G, Gardini F. Biogenic amines in dry fermented sausages: a review. Int J Food Microbiol. 2003:88:41-54

35. Bover-Cid S, Hugas M, Izquierdo-Pulido M, Vidal-Carou MC. Amino aciddecarboxylase activity of bacteria isolated from fermented pork sausages. Int J Food Microbiol. 2001;66:185-9.

36. Stratton JE, Hutkins RW, Taylor SL. Biogenic amines in cheese and others fermented foods: a review. J Food Protection. 1991;54:460-70.

37. Braem G, Stijlemans B, Van Haken W, De Vliegher S, De Vuyst L, Leroy F. Antibacterial activities of coagulase-negative staphylococci from bovine teat apex skin and their inhibitory effect on mastitis-related pathogens. J Appl Microbiol. 2014;116:1084-93.

38. Augustin J, Rosenstein R, Wieland B, Schneider U, Schnell N, Engelke G, Entian KD, Gotz F. Genetic analysis of epidermin biosynthetic genes and epidermin-negative mutants of Staphylococcus epidermidis. Eur J Biochem. 1992;204:1149-54

39. Heidrich C, Pag U, Josten M, Metzger J, Jack RW, Bierbaum G, Jung G, Sahl HG. Isolation, characterization, and heterologous expression of the novel lantibiotic epicidin 280 and analysis of its biosynthetic gene cluster. Appl Environ Microbiol. 1998;64:3140-6.

40. Fagundes PC, Ceotto H, Potter A. Vasconcelos de Paiva Brito MA, Brede D, Nes IF, Bastos Mdo C. Hyicin 3682, a bioactive peptide produced by Staphylococcus hyicus 3682 with potential applications for food preservation. Res Microbiol. 2011;162:1052-9.

41. Martinez B, Suarez JE, Rodriguez A. Lactococcin 972: a homodimeric lactococcal bacteriocin whose primary target is not the plasma membrane. Microbiol. 1996:142:2393-8.

42. Barrangou R, Fremaux C, Deveau H, Richards M, Boyaval P, Moineau S, Romero DA, Horvath P. CRISPR provides acquired resistance against viruses in prokaryotes. Sci. 2007;315:1709-12.

43. Brouns SJ, Jore MM, Lundgren M, Westra ER, Slijkhuis RJ, Snijders AP, Dickman MJ, Makarova KS, Koonin EV, van der Oost J. Small CRISPR RNAs guide antiviral defense in prokaryotes. Sci. 2008;321:960-4.

44. Marraffini LA, Sontheimer EJ. CRISPR interference limits horizontal gene transfer in staphylococci by targeting DNA. Sci. 2008;322:1843-5.

45. Selle K, Klaenhammer TR, Barrangou R. CRISPR-based screening of genomic island excision events in bacteria. Proc Natl Acad Sci U S A. 2015;112:8076-81.

46. Sapranauskas R, Gasiunas G, Fremaux C, Barrangou R, Horvath P, Siksnys V. The Streptococcus thermophilus CRISPR/Cas system provides immunity in Escherichia coli. Nucleic Acids Res. 2011;39:9275-82.

47. Hale CR, Zhao P, Olson S, Duff MO, Graveley BR, Wells L, Terns RM, Terns MP. RNA-guided RNA cleavage by a CRISPR RNA-Cas protein complex. Cell. 2009;139:945-56.

\section{Submit your next manuscript to BioMed Central and we will help you at every step:}

- We accept pre-submission inquiries

- Our selector tool helps you to find the most relevant journal

- We provide round the clock customer support

- Convenient online submission

- Thorough peer review

- Inclusion in PubMed and all major indexing services

- Maximum visibility for your research

Submit your manuscript at www.biomedcentral.com/submit 